\title{
Lightweight building envelopes in prefabricated buildings in terms of fire resistance
}

\author{
Agnes Iringová ${ }^{*}$ \\ ${ }^{1}$ University of Žilina, Faculty of Civil Engineering, Univerzitná 1, 01026 Žilina, Slovakia
}

\begin{abstract}
Dimensioning the lightweight, building envelopes in prefabricated buildings in terms of fire protection within the passive standard. Legislation. Optimizing the protection of a supporting system in prefabricated wood-based walls in terms of thermal and fire protection according to Eurocodes.
\end{abstract}

\section{Introduction}

The design and material solution has a major impact on the building's microclimate and its fire safety. In lightweight prefabricated building envelopes it is important to choose the thermal insulation and its location in relation to the supporting structure, both in terms of heat and moisture transfer, as well as in terms of fire protection. Due to the increasing requirements for thermal protection of buildings, the composition and thickness of the envelopes in prefabricated buildings changes. Depending on the type of thermal insulation used, the building's fire safety is better or worse. The paper is to evaluate the influence of the choice and location of the thermal insulation in lightweight envelopes according to the European legislation relating to the fire resistance of supporting elements using calculation in Eurocodes.

\section{Design and material solution of prefabricated supporting systems in terms of fire safety considering the building's function and fire height}

The supporting structure of lightweight sandwich envelopes usually consists of timber or steel framework. Both types of supporting structure must be fire protected. At a minimal fire height, the required fire resistance is 30 minutes. The increase in fire height typically results in higher fire resistance requirements. The paper analyses the possibilities of using different types of thermal insulation and optimal lightweight wood-based envelopes in terms of fire resistance.

The use of wood in building constructions is wide - from supporting systems including partition walls and ceilings to the final furnishing. Timber buildings are the buildings with

* Corresponding author: agnes.iringova@fstav.uniza.sk 
the wood-based supporting system and may be divided into log buildings, half-timbered buildings, timber-framed buildings (Balloon-Frame, Platform-Frame), skeletal structures, and panel structures. Usability of the tested compositions is in the last three abovementioned systems. [6]

Nowadays, the timber framework structures are the most used ones in constructing lowstorey houses. The timber framework may be interrupted at the ceiling, or continuous along its entire height. If the wall load-bearing framework is interrupted in the ceiling, i.e. the wall of the next floor is fastened directly on the ceiling structure - it is a platform-frame structure. In the balloon-frame structure, the pillars go continuously along its entire height. Pre-engineered timber buildings are similar to this system. [4]

Timber skeleton frame structures are the counterpart of the buildings made of solid timber and framework. The buildings of solid timber and framework have the linear loadbearing construction and the load from the roof and ceiling is transferred by supporting peripheral and internal walls. The load from ceilings and roofs in skeletal systems is transferred by pillars. These buildings have a more variable layout. The timber load-bearing members are typically made of glued laminated wood with the steel joint elements embedded. The building envelope, anchored to them, is generally designed as a lightweight sandwich self-supporting panel structure, e.g. the timber framework with thermal insulation. It may be placed in front of the load-bearing system, or embedded in the pillars the ideal solution in terms of thermal protection. As for fire protection, the building envelope is generally designed as a fire-compact structure with the required fire resistance EI, or EW for wood-based ones.

\section{Legislative limitations in using construction systems for wood-based buildings in terms of fire regulations}

All of the above wood-based construction systems are in terms of fire safety classified as combustible structural units. [7] The fire height of the buildings with the timber supporting system according to legislation valid in Slovakia is limited to maximal $9 \mathrm{~m}$, excepting the buildings intended for housing and accommodation (typically four-storeyed). This goes provided that the fire load calculated in the most critical fire section of such buildings is up to $60 \mathrm{~kg} / \mathrm{m}^{2}$. If the fire load is higher than $60 \mathrm{~kg} / \mathrm{m}^{2}$, the maximal allowable fire height is 4 $\mathrm{m}$. The requirement for maximal fire resistance of the load-bearing members is REI 90. According to the currently valid standards, residential buildings and houses may contain wood-based load-bearing systems up to the second floor (see Table1, column 3). At the present time, the modification of STN 920201-2 is being approved; it will allow using wood-based construction systems for upper floors (see Table1, column 4).

Table 1. Possibility to use wooden sandwich panels in residential and apartment buildings made up of combustible and combined construction system within the current and future legislation.

\begin{tabular}{|c|c|c|c|}
\hline \multirow[b]{2}{*}{$\begin{array}{l}\text { Construction } \\
\text { system }\end{array}$} & \multirow[b]{2}{*}{$\begin{array}{l}\text { Maximal } \\
\text { number of } \\
\text { above ground } \\
\text { storeys }\end{array}$} & \multicolumn{2}{|c|}{ The lowest degree of fire safety, fire zones } \\
\hline & & $\begin{array}{l}\text { Current state within } \\
\text { standard STN 920201-2 } \\
\text { valid for above ground } \\
\text { storeys }+1 \text { st basement }\end{array}$ & $\begin{array}{l}\text { State after modification } \\
\text { of standard STN } 920201-2 \\
\text { valid for above ground } \\
\text { storeys }+1 \text { st basement }\end{array}$ \\
\hline combined & $\begin{array}{l}2 \\
3 \\
5\end{array}$ & $\begin{array}{c}\text { I } \\
\text { II } \\
\text { unacceptable }\end{array}$ & $\begin{array}{c}\text { I } \\
\text { II } \\
\text { III } \\
\end{array}$ \\
\hline
\end{tabular}




\begin{tabular}{|l|l|l|c|}
\hline \multirow{3}{*}{ combustible } & 1 & I & I \\
& 2 & II & II \\
& $\mathbf{3}$ & unacceptable & III \\
\hline
\end{tabular}

\section{Requirements for the design of wood-based lightweight envelope in terms of thermal protection}

Current legislative conditions to optimize the energy performance of buildings are set in STN 735040-2: 2012 Z1 - 2016 so that the building would be supposed to meet the global indicator required - primary energy consumption in $\mathrm{kWh} /\left(\mathrm{m}^{2} . \mathrm{a}\right)$ in the energy performance class A1. The limit values are defined depending on the building's category - its main functional use. As of 2020, all the buildings designed, including those for housing (family houses and apartment buildings), will have to meet the national requirements for energy consumption in the category of nearly-zero-energy buildings within the limit of the global indicator - primary energy consumption in $\mathrm{kWh} /\left(\mathrm{m}^{2} . \mathrm{a}\right)$ in the energy performance class $\mathrm{A} 0$. In terms of the heat loss reduction, the current standard requirement for heat transfer through the building envelope is $0.22 \mathrm{~W} / \mathrm{m}^{2} \mathrm{~K}$.

Nowadays, the construction of wood-based buildings often uses the load-bearing systems of timber framework. [3] The framework in low-storey buildings serves as a building's supporting system and at the same time as a load-bearing structure for the envelope. The load-bearing structure for the envelope consists of vertical wooden pillars with an air gap filled with thermal insulation. Its exterior side may be covered with vapour permeable formwork of thermal insulation (Fig. 1), or it may be covered with OSB boards, subsequently thermo- insulated and finished with a thin-layer plaster. Its interior side may be covered with OSB boards having vapour barrier with a grid and a pre-wall of plasterboard fastened to it. Technical wiring may be situated in the air gap between the prewall and plasterboard. The plasterboard thickness is designed according to the fire resistance requirements for the supporting wall and the envelope itself. The pre-wall also makes the acoustic insulation better. [8]

Choosing the thermal insulation for sandwich timber structures is conditioned by its thermo-insulating efficiency, combustibility class, durability, and recyclability. The building envelope and timber load-bearing framework must be designed so that the water condensation would not occur on joints of timber elements. As for hygienic demands, the layers of thermal insulation and its physical parameters must be designed to keep the minimal surface temperature of the interior wall above the critical surface temperature for mould growing, depending on the boundary environmental conditions and the type of heating. The type and thickness of thermal insulation is essential for the fire resistance of a timber panel. Its melting temperature should be above $1000^{\circ} \mathrm{C}$ and a minimal mass weight should be above $30 \mathrm{~kg} / \mathrm{m}^{3}$. Thermal insulations $\mathrm{m}$ based on mineral-wool or glass-fibre meet these physical parameters. [5]

Table 2. Optimization of a timber panel - thermal insulation in terms of heat loss for structures built by 2020 .

\begin{tabular}{|c|c|c|c|c|c|}
\hline Thermo-insulating material & $\begin{array}{c}\lambda \\
\mathrm{W} / \mathrm{mK}\end{array}$ & $\begin{array}{c}\rho \\
{[\mathrm{kg} / \mathrm{m} 3]}\end{array}$ & $\begin{array}{c}\text { Combustibility } \\
\text { class }\end{array}$ & $\begin{array}{l}\text { Hr. TI } \\
{[\mathrm{m}]}\end{array}$ & $\begin{array}{c}\mathrm{Uv} \leq 0,22 \\
\mathrm{~W} /(\mathrm{m} 2 . \mathrm{K})\end{array}$ \\
\hline Gypsum plaster board, at plant & 0.22 & 750 & \begin{tabular}{|l|}
$\mathrm{A} 1$ \\
\end{tabular} & 0.015 & \\
\hline $\begin{array}{l}\text { Isover Woodsil } \\
+ \text { vapour barrier } \\
\text { in the grid of an installation pre-wall }\end{array}$ & 0.038 & 37 & A1 & 0.06 & \\
\hline Oriented strand board, at plant & 0.130 & 650 & $\mathrm{E}$ & 0.015 & \\
\hline
\end{tabular}




\begin{tabular}{|c|c|c|c|c|c|}
\hline $\begin{array}{l}\text { Variant } 1 \text { Isover Woodsil } \\
\text { Variant } 2 \text { fibreboard soft, at plant } \\
\text { Variant } 3 \text { blown cellulos }\end{array}$ & $\begin{array}{l}0.038 \\
0.040 \\
0,044\end{array}$ & $\begin{array}{l}37 \\
55 \\
50\end{array}$ & $\begin{array}{c}\mathrm{A} 1 \\
\mathrm{E} \\
\mathrm{E}\end{array}$ & $\begin{array}{l}0.12 \\
0,13 \\
0,14\end{array}$ & \multirow{4}{*}{ cca 0.17} \\
\hline Fibreboard soft, at plant & 0.043 & 55 & $\mathrm{E}$ & 0.06 & \\
\hline $\begin{array}{l}\text { Thin-layer plaster with reinforcement } \\
\text { fabric }\end{array}$ & 0.75 & 1600 & A1 & 0.001 & \\
\hline $\begin{array}{l}\text { Sawn timber, softwood, raw, kiln } \\
\text { dried, } u=10 \%\end{array}$ & 0,018 & 300 & $\mathrm{E}$ & & \\
\hline
\end{tabular}

In the lightweight sandwich structures - timber panels, the currently convenient thickness of thermal insulation based on mineral wool, fibreboards, blown cellulose, or sheep wool is about $220 \mathrm{~mm}$, depending on the mass weight and heat conductivity coefficient. As of 2020, the requirement for the thickness of thermal insulation of building envelopes in the passive houses will be a quarter higher. [9]
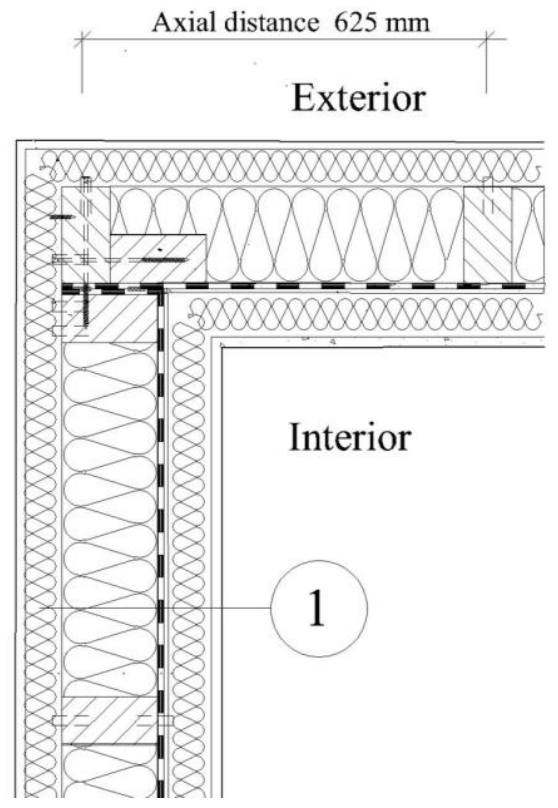

Composition 1 -from the interior side

- Gypsum fiber board thickness of $12,5 \mathrm{~mm}$

- Mineral wool thickness of $60 \mathrm{~mm}$ in the installation cavity

- Vapor barrier

- OSB boards thicknesss of $15 \mathrm{~mm}$

- Supporting Wooden columnar structure $60 / 120 \mathrm{~mm}$ inserted in the air gap insulation thickness of $120 \mathrm{~mm}$

- Fibreboards insulation thickness of $60 \mathrm{~mm}$

- Exterior plaster thickness of $10 \mathrm{~mm}$

Fig. 1. Composition of timber panel optimized in terms of higher fire resistance

\section{Fire resistance of timber sandwich panels according to Eurocode}

The required time of fire resistance and the criteria for limit states of timber loadbearing elements of external walls are directly related to the static load. In case of frameworks, the timber vertical elements are part of the supporting walls and are linked up by the horizontal ceiling or roof supporting elements. These structures, including all those of bracing and anchor elements, must meet the REI criterion.

The composite supporting elements of the fire-separating structures, as well as all the elements related to the supporting ones in terms of load, are required to meet the criteria for the fire resistance time. The interaction of all the elements provides the fire resistance of the 
whole structure. In case of timber supporting elements, the value of fire resistance can be determined by calculation methods depending on the static load using STN EN 1995-1-1 (Eurocode 5). The fire resistance of timber or wood-based load-bearing and construction elements depends on the burning and charring speed.

Methods to calculate fire resistance of structures in terms of Eurocodes employ the analytical approach to design buildings considering the fire effect. It takes into account the function of a structural system at higher temperatures in terms of static load of fire separating structures as well as increases in thermal protection by active or passive elements of fire protection systems. When designing or assessing load-bearing fire barrier according to EN 1991-1-2, the appropriate model of fire situation is chosen. Subsequently, the corresponding fire scenario is determined. According to standard temperatures in the affected fire zone, it is calculated temperature course in load-bearing structural elements which are stressed both statically and thermally. The resulting static load of a structure in a critical fire situation is calculated and the cross-section is evaluated - whether it meets supposed thermal stress in the required time.

The mechanical behaviour of statically stressed structures during fire depends on thermal load defined by fire risk, thermal effects on material properties - flammability, indirect mechanical load (release or fall of facing etc.), and direct effects of static load. Thermal analysis is carried out according to STN EN 1991-1-1-2. Static analysis is made according to STN EN 1991-1-1-2 and other STN, depending on the material type.

In accordance with the procedure, specified in STN EN 1991-1-1-2, the model fire situation was determined on the basis of an estimation or calculation of fire risk. The model (normative) fire in a fire sector (FS) is determined for the model fire situation. It is always considered only for one FS in given time; in this case the entire object is one fire sector. When assessed fire resistance of a structure, calculations considered the model (normative) fire with nominal fire curves. [1]

The charring depth and the subsequent static weakening of the cross-section must consider all the surface elements directly exposed to fire. Surface charring need not consider the surface of the timber load-bearing elements protected during the calculated fire load by other elements. Likewise, it need not be considered at the elements protected by the fire facing provided that: $t_{\mathrm{pr}} \geq t_{\mathrm{fi}, \text { req; }}$ where $t_{\mathrm{pr}}$ is the time to break the protective plate or other protective material and $t_{\mathrm{fi}, \text { req }}$ is the time required for fire protection at standard fire load.

The timber load-bearing elements of frameworks have typically double-sided covering with boards and the air gap is filled with a thermal insulator. The OSB or other wood-based boards are used for covering. Since their surface is burning more slowly than that of solid timber, they increase the fire resistance of the load-bearing elements.

Most board materials that are construction elements of the supporting system of the envelope may be also used as an additional fire protection of timber load-bearing members. They also serve as reinforcing wall elements and a foundation for the final finishing. If they are considered as a protective fire facing, the time when the breakage occurs must be determined. In such cases, the time to break is the time within the temperature on the nonradiated side of the fire barrier will increase by more than $180 \mathrm{~K}$ in combustible materials and by more than $500 \mathrm{~K}$ in non-combustible materials. These time limits are being determined by tests.

\subsection{Fire resistance of the tested timber sandwich envelopes}

The testing of envelope compositions considers covering using OSB boards on the interior side and fibreboards with a thin-layer plaster on the exterior side. Before completing the structure, the plasterboard pre-wall with an installation gap will be fastened on a wooden grid on the interior side. After wiring, the gap will be filled with mineral wool. 
This adjustment will also serve as a passive fire protection of the timber elements in the load-bearing system.

The time to break a fire protection by these structures up to the surface of timber supporting elements will be the sum of the partial values of the time when the fire damage occur. [3]

The time to break the timber and wood-based fire-protecting boards may be determined using the tests according to the relation:

$$
\mathrm{t}_{\mathrm{pr}}=\mathrm{t}_{\mathrm{p}} / \beta_{0}-\mathrm{t}_{\mathrm{r}}(\min )
$$

$\beta_{0}$ - charring speed

$\mathrm{t}_{\mathrm{p}}$ - thickness of the facing

$\mathrm{t}_{\mathrm{r}}=4 \mathrm{~mm}$; it is the reserve to prevent boards from falling down or to prevent fire from spreading into cavities (e.g. installation gaps)

The multi-layer fire facing must always be anchored to the protected supporting element.

The time to break OSB boards in the composition tested (see Fig. 2) is $13.4 \mathrm{~min}$.

The time to break the non-flammable facing and boards is the time when the temperature of the surface that is not exposed to fire rises by more than $500 \mathrm{~K}$.

For F-type plasterboards, $15 \mathrm{~mm}$ thick, with increased cohesion of the core at the high temperature, it can be determined according to the relation:

$$
\mathrm{t}_{\mathrm{pr}}=1,9 \cdot \xi \cdot \mathrm{t}_{\mathrm{p}}(\min )
$$

The time to break F-type plasterboards is $28.5 \mathrm{~min}$

The time to break non-flammable insulation materials, more than $20 \mathrm{~mm}$ thick with mass density above $30 \mathrm{~kg} / \mathrm{m}^{3}$ that remain compact to $1000^{\circ} \mathrm{C}$, can be calculated according to the relation:

$$
\mathrm{t}_{\mathrm{pr}}=0,07\left(\mathrm{t}_{\text {ins }}-20\right) \cdot \vee_{\rho_{\text {ins }}}(\text { min })
$$

$\mathrm{t}_{\text {ins }}-$ thickness of the insulation material in $\mathrm{mm}$

$\rho_{\text {ins }}$ - mass weight of the insulation material in $\mathrm{kg} / \mathrm{m}^{3}$

In this case, mineral wool with a specific weight of $37 \mathrm{~kg} / \mathrm{m}^{3}$ is used in both the pre-wall cavity.

Supporting fire barrier wall - option 1a. $\mathrm{t}_{\mathrm{pr}}=17 \mathrm{~min}$

The resultant value of $\Sigma \mathrm{t}_{\mathrm{prj}}$ for verified composition is 55 minutes. The condition corresponds to the fire resistance of a filling wall REI 30.

Curtain framework - option 1b. $\mathrm{t}_{\mathrm{pr}}=68 \mathrm{~min}$

The resultant value of $\Sigma \mathrm{t}_{\mathrm{prj}}$ for verified composition is 109 minutes. The condition corresponds to the fire resistance of a filling wall EI 60 .

The resultant value of $\Sigma \mathrm{t}_{\mathrm{prj}}$ for verified composition is 109 minutes. The condition corresponds to the fire resistance of a filling wall REI 30.

If the air gap in the framework is filled with a combustible thermal insulation with the melting temperature of $1000{ }^{\circ} \mathrm{C}$ - option 1b, 2, and 3. $\mathrm{t}_{\mathrm{pr}}=0.07(60-20) . \sqrt{3} 7=17 \mathrm{~min}$. The solution corresponds to the fire resistance of a supporting wall REI 30 .

Criterion I. - verification of the temperature rise on the side that is not exposed to fire, up to $140 \mathrm{~K}$ :

$\Sigma \mathrm{t}_{\mathrm{prj}} \geq \mathrm{t}_{\mathrm{fi}, \text { req }}+5=109>60+15 \ldots$. EI $60 \quad \ldots \ldots$ option $1 \mathrm{~b}, 2,3$. 
$\Sigma \mathrm{t}_{\mathrm{prj}} \geq \mathrm{t}_{\mathrm{fi}, \mathrm{req}}+5=55>30+15 \ldots$. REI $30 \quad \ldots \ldots$ option $1 \mathrm{a}$.

Criterion II. - verification of the maximal temperature rise in any spot is limited up to $180^{\circ} \mathrm{C}$, the condition is met if the inequation is true:
$\Sigma \mathrm{t}_{\mathrm{prj}} \geq \mathrm{t}_{\mathrm{fi}, \mathrm{req}}+5=80.8>60+5 \quad \mathrm{EI}$
option $1 b, 2,3$.
$\Sigma \mathrm{t}_{\mathrm{prj}} \geq \mathrm{t}_{\mathrm{fi}, \mathrm{req}}+5=45.5>30+5 \quad$ REI
...... option 1a.

Table 3.Fire protection of wood-based sandwich panels according to the thermal insulation used.

\begin{tabular}{|l|c|c|c|c|c|}
\hline Thermo-insulating material & $\begin{array}{c}\rho^{3} \\
{\left[\mathrm{~kg} / \mathrm{m}^{3}\right]}\end{array}$ & $\begin{array}{c}\text { Combustibility } \\
\text { class }\end{array}$ & $\begin{array}{c}\text { Melting } \\
\text { temperature }{ }^{\circ} \mathrm{C}\end{array}$ & $\begin{array}{c}\mathrm{Hr} \text {. TI } \\
{[\mathrm{m}]}\end{array}$ & $\begin{array}{c}\Delta \text { Fire } \\
\text { resistance } \\
\text { min. }\end{array}$ \\
\hline Gypsum plaster board, at plant & 750 & $\mathrm{~A} 1$ & & 0.015 & 28,5 \\
\hline $\begin{array}{l}\text { Isover Woodsil + vapour barrier } \\
\text { in the grid of an installation pre- } \\
\text { wall }\end{array}$ & 37 & $\mathrm{~A} 1$ & $>1000$ & 0.06 & 17 \\
\hline Oriented strand board, at plant & 650 & $\mathrm{E}$ & & 0.015 & 13,4 \\
\hline $\begin{array}{l}\text { Variant 1 Isover Woodsil } \\
\text { Variant 2 fibreboard soft, at plant } \\
\text { Variant 3 blown cellulos }\end{array}$ & $\begin{array}{l}37 \\
55\end{array}$ & $\begin{array}{c}\mathrm{A} 1 \\
\mathrm{E}\end{array}$ & $\begin{array}{c}>1000 \\
<1000 \\
<1000\end{array}$ & 0.12 & $\begin{array}{c}25 \\
8 \\
0\end{array}$ \\
\hline Fibreboard soft, at plant & 55 & $\mathrm{E}$ & $<1000$ & 0.06 & - \\
\hline $\begin{array}{l}\text { Thin-layer plaster with } \\
\text { reinforcement fabric }\end{array}$ & 1600 & $\mathrm{~A} 1$ & & 0.001 & - \\
\hline $\begin{array}{l}\text { Sawn timber, softwood, raw, kiln } \\
\text { dried, u=10\% }\end{array}$ & 300 & $\mathrm{E}$ & & & - \\
\hline
\end{tabular}

\section{Conclusion}

The increasing thickness of a thermal insulation, in terms of energy performance optimization, causes increasing fire resistance of the building envelopes where the noncombustible thermal insulation with the melting temperature of $1000{ }^{\circ} \mathrm{C}$ is used. Lowstorey panel buildings, as well as kit homes with framework systems, are provided with the adequate fire-resistant load-bearing members of a building envelope when choosing interior thermal insulation optimally. In timber skeleton frame structures, where the timber loadbearing members are not fire-protected, it is possible to achieve the fire resistance by overdimensioning the cross-section of load-bearing glued timber elements according to EC:5 methodology. The conditions valid for the envelope in the panel buildings are similar to those valid for wood-based filling masonry.

\section{Acknowledgements}

The paper presents results of the project VEGA 1/0945/16.

\section{References}

1. STN EN 1995-1-2, Eurocode 5, Design of wooden structures - Part 1 - 2, General rules - Design of structures for fire effect. SUTN, Bratislava (2008)

2. P. Durica: Defects in buildings - diagnostics and redevelopment (in Slovak), 1st edition. Žilina : Žilinská univerzita, (2012) 
3. Timber structures according to Eurocode 5 - step 2, Designing details and supporting systems (in Czech). ISBN 80-86 769-13-5, Praha (2004)

4. P. Durica, P. Juras, D. Staffenova, J. Rybarik, Proceedings of the Conference enviBUILD, Brno (2016)

5. L. Makovická -Osvaldová, L. - S. Gašpercová, Civil and Environmental Engineering: scientific technical journal, 11/2, 142 - 146 (2015)

6. K. Durian, P. Krušinský, R. Korenková, D.Zacharová, Fireco : X. international conference : fire protection (2013)

7. Trenčín, Slovakia, 2nd - 3rd May 2013 : conference proceedings. Bratislava: Požiarnotechnický a expertízny ústav MV SR, (2013)

8. V. Mózer, Proceedings of the 2nd European symposium on Fire safety science: Nicosia, June 16th-18th 2015. Nicosia : CERISE, European University Cyprus, 289293 (2015)

9. D. Katunský, M. Lopušniak, M. Bagoňa, E. Dolníková, J. Katunská, M. Vertal', Journal of Theoretical and Applied Information Technology. 44/1, 40-50 (2012)

10. P. Durica, P. Juras, V. Gaspierik, J. Rybarik, Procedia Engineering 111, 176-182 (2015) 